\title{
IMPACT OF TOURISM ON LINER MARITIME PASSENGer Traffic
}

\author{
Viducic, V.; TOMAsEVIC, M. \& VIDUCIC, LJ.
}

Abstract: The subject of this research is interdependence of maritime passenger liner shipping and tourism. Besides the analysis of the effect of transport on tourism, the emphasis has also been put on the effect of tourism on maritime passenger liner traffic. This paper presents the dynamics of maritime passenger liner shipping in Croatia in various navigational areas regarding the tourist offers of the islands and geographic characteristics. In the end, recommendations are given for economic policy aimed at harmonising tourist and transport politics and selecting the type of tourism which would be in compliance with sustainable development of the islands and balanced exploitation of shipping companies' capacities.

Key words: tourism, passenger traffic, seasonality, passenger ports
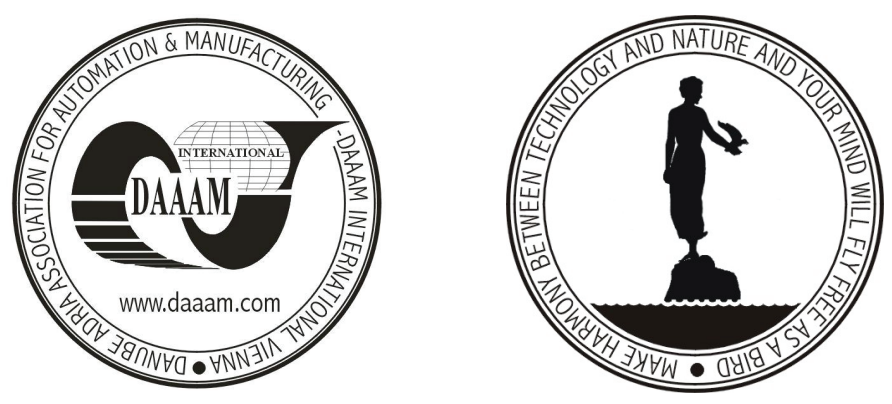

Authors' data: B.Eng. Viducic V.[inko]*, Mr.Sc. Tomasevic M.[arko]*, Prof. Viducic Lj.[iljana]**, Maritime Faculty, University of Split*, Faculty of Economis, University of Split**, Croatia, vviducic@pfst.hr, marko.tomasevic@pfst.hr, 1viducic@efst.hr

This Publication has to be referred as: Viducic, V.; Tomasevic, M. \& Viducic, Lj. (2006). Impact of Tourism on Liner Maritime Passenger Traffic, Chapter 51 in DAAAM International Scientific Book 2006, B. Katalinic (Ed.), Published by DAAAM International, ISBN 3-901509-47-X, ISSN 1726-9687, Vienna, Austria DOI: $10.2507 /$ daaam.scibook.2006.51 